Polyethylene glycol 4 ooo PEG, inert marker, was used for this purpose. It was administred in the stomach or caecum of New Zealand male rabbits from 2.5 to $4 \mathrm{~kg}$ owing to two Tygon probes (diameter : $2-3 \mathrm{~mm}$ ) fixed permanently. The animals were fed commercial pellets. They were only allowed to eat from $6 \mathrm{p}$. m. to $8 \mathrm{a} . \mathrm{m}$., the next day. The PEG was dosed by the turbidimetric method of Hyden. Owing to a fraction collector, we were able to gather fecal emissions hour by hour, when it was necessary.

\title{
Results
}

The PEG appeared in the faeces from the first hour following its administration to the animal. The emission of hard faeces was interrupted for 3 to 5 hours, period during which the rabbit fetched caecotrophes at the anus. According to our results this period was situated 15 to 20 hours after the beginning of the meal. The caecotrophes collected from the 9 th hour after PEG intake already contained some of it. These observations indicated, on the one hand, that the transit was rapid from the stomach to the anus and, on the other hand, an early contribution of the food eaten to the formation of caecotrophes.

When the animal was fitted with a carcan, the proportion of PEG recovered in the faeces was always lower than that identified in the caecotrophes (for instance 35 to $53 \mathrm{p}$. roo respectively of the $P E G$ ingested). In these conditions the amounts of $P E G$ remaining in the digestive tract became rapidly indeterminable and therefore accounted for the notion of "shortened" transit, when the animal did not eat its caecotrophes. In the normal animal, we recovered PEG up to day to after its administration.

However, PEG does not seem to be an adequate marker for studying the transit in the rabbit: it is seldom that more than 70 to $80 \mathrm{p}$. Ioo of the marker ingested are recovered and it may be that PEG, marker of the aqueous phase, is more easily recovered in the caecotrophes having a higher water content. This explains the erroneous interpretation of the results.

\section{VARIATIONS DIURNES DE QUELQUES PARAMETRES BIOCHIMIQUES DANS LE CAECUM ET LE LONG DU COLON DU LAPIN}

\author{
G. DEMAUX, L. GUEMON et H. LE BARS
}

Institut national agronomique, I. N. R. A., 16, rue Claude-Bernard, 75231 Paris Cedex 05

Dans le but de préciser le lieu de formation des cæcotrophes dans le colon et de voir si, dans le temps, il était possible d'infirmer à partir du matériel présent dans le colon, la nature de l'émission fécale, nous avons étudié les variations des paramètres biochimiques suivants : $\mathrm{pH}$, matière sèche, taux de l'Azote total $(\mathrm{N})$, taux des acides gras volatils totaux (AGV). Une étude complémentaire nous aménera à préciser la nature des acides et leur variation respective.

Des lapins mâles Néo-Zélandais pesant de 2,5 à $4 \mathrm{~kg}$, nourris ad libitum de granulés du commerce, sont sacrifiés par choc cervical à $8 \mathrm{~h}$ le matin, entre $\mathrm{I}_{3}$ et $\mathrm{I} 5 \mathrm{~h}$ et entre I $8 \mathrm{~h} 30$ et I9 h 30 le soir.

Annales de Biologie animale. - I973. 


\section{Résultats}

Les variations du $\mathrm{pH}$ sont minimes sur l'ensemble du colon $(0,3$ à 0,5 unités $\mathrm{pH})$. La valeur du $\mathrm{pH}$ augmente le long du colon proximal mais diminue dans le dernier quart du colon distal. Les variations $\mathrm{du} \mathrm{pH}$ dans le colon proximal reflètent bien la diminution du taux des AGV constatée dans ce segment. Le taux des AGV continue à décroître dans le colon distal ( $\mathrm{I}^{\mathrm{er}}$ tiers) mais on constate une augmentation très nette de ce taux chez les animaux sacrifiés à I3-15 heures, pour lesquels on peut dissocier les deux formes, fèces vraies et cæcotrophes, dès le deuxième quart du colon distal. La forme "cæcotrophe " contenant toujours davantage d'AGV, d'N total et moins de matière sèche.

Chez les animaux sacrifiés à 8 heures le matin, les variations des taux du $\mathrm{pH}$, de la matière sèche et de l'azote sont faibles ( $\mathrm{pH}$ : écart de 0,2 unités, matière sèche $7 \mathrm{p}$. Ioo, azote écart de $7 \mathrm{mg} / \mathrm{g} \mathrm{sec}$ ).

Le colon proximal constitue donc un réservoir dans lequel le matériel "fécal " continue à s'élaborer, ce n'est que dans le dernier tiers de ce segment colique que la fragmentation du contenu se manifeste.

Le colon distal est le lieu où une différenciation entre fèces vraies et cæcotrophes est décelable. Quand des cæcotrophes s'y élaborent l'absorption d'eau est moins intense, l'azote total et les $\mathrm{AGV}$ sont en augmentation indiquant une absence d'absorption et même une néoformation de métabolites.

\section{SUMMARY}

\section{DIURNAI, VARIATIONS OF SOME BIOCHEMICAL PARAMETERS IN THE, CAECUM AND ALONG THE, COLON IN THE RABBIT}

In order to define the site of formation of caecotrophes in the colon and to find out, from the material present in the colon, if it was possible to call in question, through measurements made at different moments of the day, the nature of the faecal emission, we studied the variations of the following biochemical parameters : $\mathrm{pH}$, dry matter, total nitrogen content $(\mathrm{N})$, amount of total volatile fatty acids (VFA). A supplementary study will allow to determine more accurately the nature of the acids and their respective variation.

New Zealand male rabbits weighing between 2.5 and $4 \mathrm{~kg}$, fed ad libitum commercial pellets, were killed by cervical choc at 8 a. m., between I p. m. and 3 p. m. and between $6.3^{\circ} \mathrm{p}$. m. and 7.30 p. m.

\section{Results}

$\mathrm{pH}$ variations were very small in the colon ( 0.3 to $0.5 \mathrm{pH}$ units). The $\mathrm{pH}$ value increased along the proximal colon, but decreased in the last quarter of the distal colon. $\mathrm{pH}$ variations in the proximal colon very well reflected the decrease in the amount of VFA noted in this segment. The VFA content went on decreasing in the distal colon (Ist third), but a definite increase of this content was recorded in the animals killed at I-3 P. m. in which the two kinds of faeces : "normal" faeces and caecotrophes, can be dissociated from the second quarter of the distal colon. The caecotrophes always contained more VFA, more total $\mathrm{N}$ and less dry matter than the "normal " faeces.

In the animals killed at $8 \mathrm{a} . \mathrm{m}$., the variations in the levels of $\mathrm{pH}$, dry matter and nitrogen were low ( $\mathrm{pH}$ : difference of 0.2 unit; dry matter : $7 \mathrm{p}$. Ioo; nitrogen : difference of $7 \mathrm{mg} / \mathrm{g}$ dry matter.)

Thus, the proximal colon constitutes a reservoir in which the "faecal " material goes on developing. It is only in the last third of this segment of the colon that the fragmentation of the content takes place. 
A differenciation between " normal "faeces and caecotrophes can be detected in the distal colon. When caecotrophes are developing, the water absorption is less intense, total nitrogen and VFA are increasing, which indicates an absence of absorption and even a neoformation of metabolites.

\title{
OBSERVATIONS SUR LE TRANSIT DES ALIMENTS LIQUIDES A U NIVEAU DE LA GOUTTIẼRE GESOPHAGIENNE CHEZ LE VEAU PRÉRUMINANT ET RUMINANT
}

\author{
R. GUILHERMET, C. M. MATHIEU et R. TOULLEC \\ Laboratoire de Zootechnie, \\ Centre de Recherches de Rennes, I. N. R. A., \\ 65, rue de Saint Brieuc, \\ 35042 Rennes Cedex
}

Le fonctionnement de la gouttière œsophagienne a été étudié en mesurant la proportion de l'aliment liquide ingéré retrouvée dans le rumen après le repas. Pour cela i 6 veaux mâles (2 Pie Rouge, I4 Frisons) ont été munis d'une fistule du rumen vers l'âge de 3 semaines. Le polyéthylène glycol 4 ooo a été utilisé comme marqueur, il a été introduit d'une part directement par la fistule ( 5 à $50 \mathrm{~g}$ selon l'âge et le régime) pour déterminer le volume du liquide ruminal (Hyden, I96I) et d'autre part dans l'aliment (concentration de 2 à 5 p. Ioo selon l'âge et la quantité offerte) pour déterminer la concentration en polyéthylène glycol du liquide ruminal aussitôt après le repas. Ces deux mesures ont été effectuées à 48 heures d'intervalle. L.es aliments ont été distribués au seau.

I. Six veaux préruminants de race Frisonne, alimentés au lait entier, ont été maintenus au stade préruminant jusqu'à l'âge de 6 mois; $80 \mathrm{p}$. Ioo au moins de lait ingéré ont toujours courtcircuité le rumen jusqu'à l'âge de 3 mois; au-delà de cet âge, des proportions de lait supérieures à $20 \mathrm{p}$. Ioo ont parfois été retrouvées dans le rumen (tabl. I, régime I). Cependant, chez un veau préruminant de race Pie Rouge, alimenté dans les mêmes conditions, plus de 20 p. Ioo du lait ont été retrouvés dans le rumen dans $3^{8} \mathrm{p}$. Ioo des essais jusqu'à l'âge de 3 mois.

2. Deux veaux ruminants ont continué à recevoir du lait entier. La fréquence des essais où plus de $20 \mathrm{p}$. Ioo du lait ont été retrouvés dans le rumen a été peu importante jusqu'à l'âge d'un an. Elle a cependant été plus élevée que chez les veaux préruminants de même âge (tabl. I, régime 2).

3. Deux veaux ruminants ont reçu une buvée exempte d'éléments lactés, en remplacement de l'aliment d'allaitement à partir de l'âge de 7 semaines.La buvée a été retrouvée en faible proportion dans le rumen jusqu'à l'âge de 4 mois; il en a été de même entre les âges de 7 et 8 mois après une interruption de 2 mois dans la distribution de la buvée (tabl. I, régime 3).

4. Trois veaux préruminants ont reçu occasionnellement une suspension de tourteau de soja $(\mathrm{roo} \mathrm{g} / \mathrm{kg})$ ou de concentré protéique de poisson $(70 \mathrm{~g} / \mathrm{kg})$, en substitution au lait distribué habituellement. Dans tous les cas (1 2 mesures), moins de $20 \mathrm{p}$. Ioo de l'aliment étudié ont été retrouvés dans le rumen. Cependant chez 2 autres veaux, une solution de poudre de lactosérum (65 ou I $30 \mathrm{~g}$ ) $\mathrm{kg}$ ), distribuée dans les mêmes conditions ( 12 mesures) a été retrouvée en proportion plus importante dans le rumen (plus de $20 \mathrm{p}$. Ioo dans $75 \mathrm{p}$. Ioo des essais et plus de $50 \mathrm{p}$. 100 dans $25 \mathrm{p}$. 100 des essais). 